Terakreditasi Sinta 3 | Volume 3 | Nomor 4 (Special Issue) | Tahun 2020 | Halaman 373-384

P-ISSN 2615-725X | E-ISSN 2615-8655

http://diglosiaunmul.com/index.php/diglosia/article/view/146

\title{
PENGEMBANGAN MEDIA AUDIO VISUAL MENGGUNAKAN CONTEXTUAL TEACHING AND LEARNING (CTL) DALAM PEMBELAJARAN MENULIS PARAGRAF NARASI PADA SISWA KELAS VII SMP
}

\author{
The Development of Audio-Visual Media Using Contextual Teaching \\ and Learning (CTL) in the Learning of Writing Narrative Paragraph \\ for Class VII Students of Junior High School
}

\author{
M. Bahri Arifin ${ }^{1, *}$ dan Yulinda Ari Wardani ${ }^{2}$ \\ ${ }^{1,2}$ Universitas Mulawarman, Samarinda \\ Kalimantan Timur, Indonesia \\ 1,* Pos-el Korespondensi: mbahriarifin12@gmail.com
}

\begin{abstract}
The purpose of this study was to develop an audio-visual media design in learning to write narrative text using the Contextual Teaching and Learning model and to determine the feasibility of audio-visual media designed for learning in junior high schools. This development is expected to help teachers in the learning process and attract students to participate in learning to write narrative paragraphs actively. This development research uses a qualitative approach with a development model, according to Alessi and Trollip (2001). Initial data were obtained for needs analysis before developing instructional media. Meanwhile, the data validated by design experts, linguists, and material experts are used to determine the feasibility of the media that has been developed. The data collection was done by using a questionnaire method. Development is carried out in three stages, namely planning, design, and development. The results of the due diligence of the three experts are as follows. The results of the media expert's feasibility test got a score of 40 with a percentage of $90.91 \%$, so it was categorized as very feasible. The linguist gave a feasibility test score of 22 with a percentage of $91.67 \%$ and was categorized as very feasible. The feasibility test of the material expert scored 42 with a percentage of $87.5 \%$ and was categorized as very feasible. Based on these results, it can be concluded that the developed audio-visual media has met the very feasible criteria.
\end{abstract}

Keywords: development of learning media, audio visual media, writing narrative text, contextual teaching and learning

\begin{abstract}
Abstrak: Tujuan penelitian ini adalah mengembangkan desain media audio visual pada pembelajaran menulis teks naratif menggunakan model Contextual Teaching and Learning, serta mengetahui kelayakan media audio visual yang dirancang untuk pembelajaran di SMP. Pengembangan ini diharapkan dapat membantu guru dalam proses pembelajaran dan menarik siswa untuk berpartisipasi aktif dalam pembelajaran menulis paragraf narasi. Penelitian pengembangan ini menggunakan pendekatan kualitatif dengan model pengembangan menurut Alessi \& Trollip (2001). Data awal diperoleh untuk analisis kebutuhan sebelum melakukan pengembangan media pembelajaran. Sedangkan data hasil validasi oleh ahli desain, ahli bahasa, dan ahli materi digunakan untuk mengetahui tingkat kelayakan media yang telah dikembangkan. Adapun pengumpulan data dilakukan dengan metode kuesioner. Pengembangan dilakukan dengan tiga tahapan, yaitu planning (perencanaan), design (mendesain model), dan development (pengembangan). Hasil uji kelayakan dari tiga ahli adalah sebagai berikut. Uji kelayakan ahli media mendapat skor 40 dengan persentase 90,91\% sehingga dikategorikan sangat layak. Ahli bahasa memberikan skor uji kelayakan sebesar 22 dengan persentase $91,67 \%$ dan dikategorikan sangat layak. Uji kelayakan dari ahli materi mendapat nilai sebesar 42 dengan persentase $87,5 \%$ dan
\end{abstract}


dikategorikan sangat layak. Berdasarkan hasil tersebut dapat disimpulkan bahwa media audio visual yang dikembangkan telah memenuhi kriteria sangat layak.

Kata kunci: pengembangan media pembelajaran, media audio visual, menulis paragraf narasi, pembelajaran kontekstual

\section{A. PENDAHULUAN}

Pembelajaran bahasa di sekolah bertujuan agar siswa memiliki dua kemampuan, yaitu kemampuan reseptif yang mencakup keterampilan mendengar kan dan membaca, serta kemampuan produktif yang mencakup keterampilan berbicara dan menulis. Di antara kedua kemampuan di atas, yang paling sulit dicapai adalah kemampuan produktif yang mencakup keterampilan berbicara dan menulis. Keterampilan menulis merupakan salah satu kemampuan dasar yang amat diperlukan, baik di sekolah maupun dalam kehidupan sehari-hari. Di sekolah, keterampilan menulis diperlukan untuk kegiatan mencatat, menyalin dan membuat karya tulis pada semua mata pelajaran mulai dari tingkat pendidikan dasar sampai pendidikan tinggi. Di dalam kehidupan sehari-hari keterampilan menulis diperlukan pada semua bidang kehidupan/pekerjaan, misalnya suratmenyurat baik pribadi maupun resmi, mengisi formulir, menyusun makalah, menulis pidato, membuat catatan-catatan untuk diri sendiri dan orang lain. Jadi keterampilan menulis merupakan hal yang sangat penting bagi keberhasilan siswa dalam studinya. Dengan keterampilan menulis, siswa dapat menyelesaikan tugastugas yang berkenaan dengan pelajarannya di samping juga dukungan keterampilan berbahasa yang lainnya seperti: mendengarkan, berbicara dan membaca (Winaya, Santyasa, \& Rasana, 2013).

Selama ini siswa masih menganggap pembelajaran keterampilan menulis merupakan suatu pembelajaran yang membosankan dan sulit dilakukan. Rasa membosankan dan kesulitan yang muncul dari diri siswa tidak hanya disebabkan oleh siswa itu sendiri tetapi juga disebabkan oleh guru yang belum berhasil membuat siswa tertarik terhadap pembelajaran Bahasa Indonesia terutama pada pembelajaran menulis. Guru hendaknya memfasilitasi siswanya dengan menerapkan pembelajaran yang inovatif yang kemudian mampu membuat siswasiswanya pandai dalam hal tulis menulis. Salah satu pembelajaran yang inovatif di antaranya guru harus menciptakan pembelajaran yang menarik dan menyenangkan serta disesuaikan dengan usia dan karakteristik siswa. Pembelajaran tersebut yaitu dengan memanfaatkan media yang merangsang siswa untuk berpikir kreatif.

Pembelajaran dikatakan sebagai sistem karena di dalamnya terdapat komponen-komponen yang saling berkaitan untuk mencapai suatu tujuan pembelajaran yang telah ditentukan. Komponen-komponen tersebut di antaranya adalah; tujuan, materi, metode, media dan evaluasi. Dalam evaluasi pembelajaran melibatkan dua pihak, yaitu sumber belajar dan penerima pesan. Faktor utama yang menjadi keberhasilan dalam sebuah pembelajaran adalah proses belajar dan perubahan tingkah laku siswa. Oleh karena itu dari keempat komponen tersebut sangat dibutuhkan dalam proses pembelajaran di antaranya adalah media pembelajaran.

Pada revolusi industri 4.0 ini tentunya perkembangan teknologi informasi dan komunikasi makin berdampak besar dalam kehidupan sehari-hari, termasuk di bidang Pendidikan. Sarana pembelajaran berbasis teknologi tentunya perlu dilibatkan dalam proses pembelajaran. Saat ini, media pembelajaran merupakan hal yang sudah mulai banyak digunakan dalam proses pembelajaran. Baik media 
pembelajaran berbantu komputer maupun media aplikasi yang berbantu di ponsel android (Yulianti, 2020). Pemanfaatan teknologi internet di dalam kegiatan pembelajaran berupa penggunaan media pembelajaran daring berbasis teknologi dan informasi mempunyai beragam jenis. Keberagaman media yang mudah diakses tersebut jika dimanfaatkan dengan maksimal dapat membantu proses penyampaian materi dengan cara yang lebih bervariasi.

Media memiliki peranan yang sangat penting untuk menunjang ketercapaian tujuan pembelajaran. Pemilihan media pembelajaran haruslah tepat untuk mendukung penguasaan kompetensi yang diharapkan. Penggunaan media pembelajaran yang cocok dengan materi yang disampaikan oleh guru dapat menarik perhatian siswa untuk mengikuti proses pembelajaran dengan baik. Salah satu media yang digunakan untuk merangsang imajinasi siswa dalam menulis narasi pada pembelajaran bahasa Indonesia, yaitu media video (audio visual).

Menurut Syah \& Risnawati (2019) video sangat efektif untuk membantu proses pembelajaran. Penggunaan video dalam pembelajaran menulis diharapkan dapat merangsang imajinasi siswa untuk mengungkapkan ide atau gagasannya serta mempermudah siswa dalam menulis. Selain itu, video dapat menghilangkan kejenuhan dan kebosanan siswa dalam proses belajar sehingga akan berdampak pada aktivitas belajar siswa yang lebih baik dari sebelumnya.

Salah satu pembelajaran bahasa Indonesia pada keterampilan menulis yang sering mengalami kendala adalah menulis paragraf narasi. Pembelajaran menulis teks narasi ternyata dikatakan cukup sulit ketika diterapkan di pembelajaran SMP. Paragraf narasi mempunyai tujuan menceritakan suatu peristiwa atau kejadian yang ada pada teks wawancara dan berusaha menceritakan alur cerita, latar, serta konflik suatu peristiwa atau kejadian sasaran utamanya adalah tindak tanduk yang dijalin dan dirangkaikan menjadi sebuah peristiwa yang terjadi dalam suatu kesatuan waktu.

Dari observasi pendahuluan yang dilakukan di beberapa SMP se-Kabupaten Kutai Kartanegara, siswa belum memiliki kemampuan menulis yang maksimal. Berdasarkan hasil wawancara guru Bahasa Indonesia, diperoleh bahwa selama ini kemampuan menulis siswa menemukan berbagai hambatan. Salah satunya siswa belum mampu memilih perbendaharaan kata, apalagi membuat sebuah kalimat efektif. Siswa terkadang memilih kata yang tidak sesuai dengan KBBI dan memilih menggunakan bahasa daerah. Selain itu, menurut siswa, menulis narasi atau menulis paragraf lainnya memang lebih sulit untuk memilih diksi yang benar dan menyusun sebuah kalimat menjadi kalimat efektif. Terkadang siswa bingung untuk menuangkan ide-ide tersebut menjadi sebuah cerita yang baik. Dalam menulis teks narasi siswa lebih memilih tema yang diambil berdasarkan kesukaannya terhadap komik atau berdasarkan film yang ditonton.

Keberhasilan dalam proses menulis juga dipengaruhi oleh kesiapan dan kesanggupan guru dalam mengelola proses pembelajaran yang inovatif yang hendaknya mendapat perhatian yang utama dan dikembangkan secara profesional. Oleh karena itu, maka tujuan penelitian ini adalah mengembangkan desain media audio visual pada pembelajaran menulis teks naratif menggunakan model Contextual Teaching and Learning, serta mengetahui kelayakan media audio visual yang dirancang untuk pembelajaran di SMP. Pengembangan ini diharapkan dapat membantu guru dalam proses pembelajaran dan menarik siswa untuk berpartisipasi aktif dalam pembelajaran menulis paragraf narasi.

Model Contextual Teaching and Learning (CTL) atau dalam bahasa Indonesia dikenal dengan pembelajaran kontekstual 
adalah konsep belajar yang membantu guru mengaitkan antara materi yang diajarkannya dengan situasi dunia nyata siswa dan mendorong siswa membuat hubungan antara pengetahuan yang dimilikinya dengan penerapannya dalam kehidupan mereka sehari-hari, dengan melibatkan tujuh komponen utama pembelajaran efektif, yakni: konstruktivisme (constructivism), bertanya (questioning), menemukan (inquiry), masyarakat belajar (learning community), pemodelan (modeling), refleksi (reflection) dan penelitian sebenarnya (authentic assessment) (Hasibuan, 2014).

Model kontekstual dalam pembelajaran merupakan suatu konsepsi yang membantu siswa mengaitkan konten mata pelajaran dengan situasi dunia nyata dan memotivasi siswa membuat hubungan antara pengetahuan dan penerapannya dalam kehidupan mereka sehari-hari. Proses pembelajaran kontekstual memfasilitasi siswa secara aktif bekerja dan mengalami, bukan transfer pengetahuan dari pikiran guru ke pikiran siswa. Siswa tidak lagi menjadi pengamat yang pasif tetapi menjadi aktif dan bertanggung jawab terhadap proses belajarnya. Pendekatan kontekstual memungkinkan siswa untuk menguatkan, memperluas, dan menerapkan pengetahuan dan keterampilan akademik mereka dalam kehidupan mereka, baik di sekolah maupun di luar sekolah. Hal ini terjadi karena gagasan yang ditemukan sendiri oleh siswa akan membuat mereka lebih lama mengerti dibandingkan menggunakan gagasan yang baru sebagai alternatif (Santyasa, 2011).

Ada delapan komponen yang menjadi karakteristik dalam pembelajaran kontekstual, yaitu: (1) melakukan hubungan yang bermakna (making meaningfull connection); (2) melakukan kegiatan-kegiatan yang signifikan (doing significant work); (3) belajar yang diatur sendiri (self-regulated learning); (4) bekerja sama (collaborating); (5) berpikir kritis dan kreatif (critical and creative thinking); (6) mengasah atau memelihara pribadi siswa (nurturing the individual); (7) mencapai standar yang tinggi (reaching high standard); dan (8) menggunakan penilaian autentik (using authentic assessment) (Nurhadi, 2002).

Dengan adanya pembelajaran dengan CTL siswa dapat belajar dengan menyenangkan, lebih termotivasi belajar, aktif mencari dan membangun sendiri pengetahuannya, dan siswa menjadi lebih mudah memahami dan menerima materi yang dipelajari. Dengan adanya pemahaman materi tersebut maka akan dapat membantu meningkatkan hasil belajar siswa. Berdasarkan latar belakang masalah yang telah dikemukakan di atas, penulis melakukan penelitian untuk meningkatkan keterampilan menulis karangan narasi melalui pendekatan CTL.

Dalam era perkembangan ilmu pengetahuan dan teknologi yang begitu pesat dewasa ini, profesionalisme guru tidak cukup hanya dengan kemampuan membelajarkan siswa, tetapi juga harus mampu mengelola informasi dan lingkungan untuk memfasilitasi kegiatan belajar siswa. Menyediakan lingkungan belajar siswa yang meliputi tempat belajar, metode, media, sistem penilaian serta sarana dan prasarana yang diperlukan untuk mengemas pembelajaran dan mengatur bimbingan belajar sehingga memudahkan siswa belajar. Media dalam pembelajaran sangat dipentingkan sebagai upaya untuk meminimalisir isu verbalisme.

Untuk mencapai tujuan kurikulum pembelajaran pada proses belajar mengajar maka perlu didukung media dan bahan ajar yang baik yaitu bahan ajar yang mampu menarik minat peserta didik, sesuai dengan zaman dan tidak menyimpang dari kurikulum. Penyajian materi pelajaran pada pokok bahasan dengan menggunakan video pendidikan diharapkan menarik minat peserta didik, membangkitkan gairah peserta didik untuk mempelajari kembali materi yang disajikan melalui multimedia (teks, citra, audio, 
video) materi yang disajikan dengan berbagai warna dan gambar yang sangat menarik dan sebagainya (Devi, Hudiyono, \& Mulawarman, 2018).

Melalui media yang telah dikembangkan peserta didik dapat menggunakan secara optimal alat indera yang dimilikinya. Semakin banyak alat indera yang digunakan oleh peserta didik maka sesuatu yang dipelajari akan makin mudah diterima dan diingat, akhirnya media dapat memotivasi peserta didik untuk belajar lebih baik. Selain penggunaan model pembelajaran, penggunaan media pembelajaran juga sangat diperlukan dalam kegiatan pembelajaran. Fakta di lapangan menunjukkan bahwa guru masih kurang dalam menggunakan media pada proses pembelajaran.

Dengan adanya media pembelajaran dapat membangkitkan semangat belajar siswa. Penggunaan media pembelajaran sangat membantu keefektifan proses pembelajaran, penyampaian pesan, dan isi pembelajaran pada saat itu. Selain membangkitkan motivasi dan minat siswa, media pembelajaran juga dapat membantu siswa meningkatkan pemahaman, menyajikan data dengan menarik dan terpercaya, memudahkan penafsiran data, dan memadatkan informasi.

Media audio visual merupakan salah satu jenis media pembelajaran yang dapat digunakan dalam proses pembelajaran. Media audio visual adalah jenis media yang digunakan dalam kegiatan pembelajaran dengan melibatkan pendengaran dan penglihatan sekaligus dalam satu proses atau kegiatan. Pesan dan informasi yang dapat disalurkan melalui media ini dapat berupa pesan verbal dan nonverbal yang mengandalkan baik penglihatan maupun pendengaran. Beberapa contoh media audio visual adalah film, video, program TV, dan lain-lain. Media audio visual merupakan media yang dapat digunakan dalam kegiatan pembelajaran dengan melibatkan pendengaran dan penglihatan sekaligus dalam satu proses atau kegiatan (Devi et al., 2018).

Pembelajaran menggunakan teknologi audio visual adalah satu cara menyampaikan materi dengan menggunakan mesin-mesin mekanis dan elektronis untuk menyajikan pesan-pesan audio visual. Arsyad (2016) mengemukakan bahwa media audio visual memiliki karakteristik bersifat linear, menyajikan visual yang dinamis, digunakan dengan cara yang telah ditetapkan sebelumnya oleh perancang/pembuatnya, dapat memberikan gambaran fisik dari gagasan real atau abstrak, dikembangkan menurut prinsip psikologis behaviorisme dan kognitif, dan berorientasi pada guru dengan tingkat penglihatan interaktif murid yang rendah.

Dale mengemukakan bahwa media audio visual atau video dapat memberikan banyak manfaat asalkan guru berperan aktif dalam proses pembelajaran. Penggunaan media audio visual digunakan karena lebih efisien dan juga membuat hasil belajar lebih bermakna bagi kemampuan siswa, terutama dalam pembelajaran menulis. Siswa dimudahkan dalam menulis paragraf dengan adanya video (Arsyad, 2016).

\section{B. METODE}

Penelitian ini merupakan penelitian pengembangan dengan pendekatan kualitatif. Pada penelitian ini digunakan model pengembangan menurut Alessi \& Trollip (2001). Penggunaan model pengembangan ini karena model ini memang dikhususkan untuk mengembangkan multimedia pembelajaran-dalam penelitian ini adalah media audio visual (video). Data awal diperoleh untuk analisis kebutuhan sebelum melakukan pengembangan media pembelajaran. Sedangkan data hasil validasi oleh ahli desain, ahli bahasa, dan ahli materi digunakan untuk mengetahui tingkat kelayakan media yang telah 
dikembangkan. Adapun pengumpulan data dilakukan dengan metode kuesioner. Tahap pengembangan meliputi tahap planning (perencanaan), design (mendesain model), dan development (pengembangan) (Alessi \& Trollip, 2001; Munandar \& Surjono, 2017).

Prosedur penelitian dan pengembangan ini adalah sebagai berikut (Ardiyanti, Safitri, \& Susanti, 2019). Tahap pertama adalah planning yang dilakukan dengan analisis masalah, analisis kebutuhan, dan pengumpulan bahan. Tahap kedua adalah design, yaitu pengembangan produk awal, pembuatan flowchart, dan storyboard untuk mempermudah pelaksanaan pembuatan video pembelajaran. Tahap ketiga adalah development, dilakukan produksi video dan audio, uji alpa, dan revisi. Pengembangan tidak menggunakan uji coba lapangan (uji beta dan uji efektivitas) pada tahap development mengingat adanya pandemi Covid-19 sehingga uji coba ditiadakan.

Data validasi yang diperoleh dari ketiga ahli dianalisis secara deskriptif kualitatif dan dijadikan sebagai acuan untuk merevisi produk sehingga menghasilkan produk yang layak. Desain produk yang dikembangkan dinilai oleh ketiga ahli dengan menggunakan lembar validasi sebanyak dua kali, yaitu tahap 1 (produk awal) dan tahap 2 (revisi produk). Adapun kategori kelayakan produk didasarkan pada kriteria yang dikemukakan oleh Sudjana (2005) sebagaimana Tabel 1.

Tabel 1. Kategori Kelayakan Produk

\begin{tabular}{cc}
\hline Persentase & Kategori \\
\hline $80-100 \%$ & Valid (Sangat Layak) \\
$60-79 \%$ & Cukup Valid (Layak) \\
$50-59 \%$ & Kurang Valid (Kurang Layak) \\
$<50 \%$ & Tidak Valid (Tidak Layak) \\
\hline
\end{tabular}

\section{PEMBAHASAN}

Pada bagian ini akan dipaparkan terkait proses pengembangan produk dan analisis kelayakan oleh ahli media, ahli materi, dan ahli bahasa. Produk pengembangan yang dihasilkan adalah media pembelajaran audio visual berupa video pembelajaran dengan materi paragraf narasi untuk kelas VII SMP. Pengembangan media audio visual (video pembelajaran ini) di sesuaikan dengan KD 3.4 mata pelajaran Bahasa Indonesia, yaitu "menelaah struktur dan kebahasaan teks narasi (cerita fantasi) yang didengar dan dibaca."

\section{Proses Pengembangan}

Proses pengembangan dilakukan dengan mengikuti konsep Alessi \& Trollip (2001) yang meliputi tahap planning (perencanaan), design (mendesain model), dan development (pengembangan). Dari model tersebut, pengembangan video pembelajaran memiliki beberapa langkah untuk menunjang kelancaran pelaksanaan pengembangannya. Adapun rincian tiap tahap adalah sebagai berikut.

Pada tahap perencanaan (planning) dilakukan tiga langkah sebagaimana dipaparkan pada metode penelitian. Langkah pertama adalah analisis masalah. Pada langkah ini dilakukan analisis potensi masalah dengan cara melakukan wawancara dengan guru SMP. Selanjutnya dilakukan analisis kebutuhan. Kemudian mengumpulkan sumber yang dapat digunakan untuk menunjang pembuatan video. Untuk mendapatkan informasi mengenai kebutuhan media pembelajaran bahasa Indonesia, digunakan teknik wawancara pada pelaksanaan focus group discussion (FGD). Hasil FGD menunjukkan bahwa hasil pembelajaran materi teks narasi belum cukup memuaskan, dilihat dari adanya beberapa siswa yang tidak memenuhi nilai standar ketuntasan minimal. Di sisi lain, pembelajaran bahasa Indonesia jarang menggunakan media 

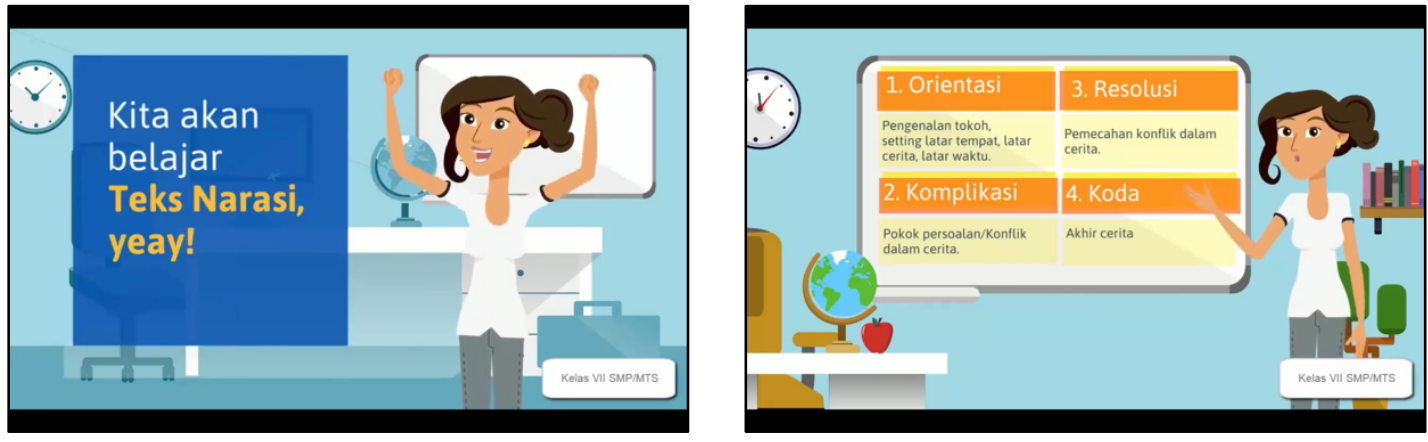

\section{Gambar 1. Media Pembelajaran Audio Visual}

pembelajaran yang inovatif. Selain itu, fasilitas media yang digunakan selama pembelajaran kurang inovatif sehingga siswa membutuhkan adanya variasi baru dalam belajar. Identifikasi kebutuhan juga dilakukan dari sudut pandang siswa dengan cara menyebarkan angket ke beberapa siswa kelas VII. Setelah mengidentifikasi kebutuhan guru dan siswa, langkah selanjutnya adalah merumuskan tujuan pembelajaran yang diturunkan dari kompetensi dasar.

Tahap kedua adalah design. Tahap ini terdiri atas tiga langkah, yaitu pengembangan produk awal, pembuatan flowchart, dan storyboard. Langkah yang pertama yaitu mengembangkan produk awal, pada tahap ini peneliti mengembangkan produk awal yang sesuai dengan tujuan pembelajaran yang telah ditentukan untuk dimuat dalam media pembelajaran yang akan dikembangkan. Langkah kedua adalah pembuatan flowchart. Pembuatan flowchart dilakukan untuk mempermudah pelaksanaan pembuatan video pembelajaran. Pada langkah ini dibuat rancangan gambar dari program yang akan dibuat. Alur program yang dibuat harus jelas agar mempermudah proses produksi media pembelajaran. Setelah membuat flowchart langkah selanjutnya yaitu membuat storyboard. Pada langkah ketiga, dilakukan perencanaan (drafting), penulisan dan revisi storyboard, beserta tampilan, animasi, grafik, dan musik, kemudian memvalidasinya. Pada tahap ini pula dilakukan persiapan skrip, yaitu perencanaan narasi, instrumen, animasi pada video. Storyboard ini berguna untuk membuat desain mengenai tahapan dan bagian yang terdapat dalam proses produksi media. Pembuatan storyboard ini mengacu dengan flowchart yang telah dibuat sebelumnya.

Tahap ketiga adalah tahap pengembangan (development) yang terdiri atas empat langkah tahapan. Tahap pengembangan ini merupakan implementasi dari rancangan media yang telah dibuat. Tahap pertama adalah produksi media pembelajaran. Produksi ini merupakan pembuatan video dan audio yang meliputi pembuatan tampilan, animasi, grafik, musik, narasi, dan instrumen yang dapat mendukung pengembangan. Pada tahap ini juga dilakukan proses menyiapkan komponen pendukung dan memprogram materi (tahap penggabungan semua materi yang dikembangkan termasuk aplikasi program yang akan digunakan). Aplikasi yang digunakan dalam proses pembuatan video adalah aplikasi Powtoon. Tahap kedua adalah uji alpa. Pada uji alpa dilakukan validasi oleh ahli sebagai dasar kelayakan produk. Uji alpa ini dilakukan oleh tiga orang ahli, yaitu ahli media, ahli bahasa, dan ahli materi. Setelah dilakukan tahap uji alpa, kemudian dilakukan tahap revisi produk sesuai dengan hasil validasi ketiga ahli. Terakhir dilakukan uji coba lapangan, yang mencakup uji beta dan uji efektivitas. Akan tetapi karena adanya pandemi 
Covid-19, maka uji beta dan uji efektivitas ditiadakan.

Gambar 1 adalah beberapa tangkapan layar dari produk video pembelajaran yang telah dikembangkan.

\section{Analisis Uji Kelayakan}

Validasi atau uji kelayakan terhadap produk media pembelajaran audio visual merupakan bagian dari uji alpa yang dilakukan untuk menilai produk awal dan produk setelah dilakukan perbaikan. Uji kelayakan dilakukan oleh tiga orang ahli, yaitu ahli materi, ahli media, dan ahli bahasa. Masing-masing ahli akan memberikan penilaian sebanyak dua kali. Penilaian tahap 1 dilakukan terhadap produk awal, dan penilaian tahap 2 dilakukan pada produk yang telah direvisi berdasarkan hasil penilaian ketiga ahli di tahap 1.

Dari Tabel 2 terlihat bahwa media pembelajaran audio visual awal yang diproduksi masih dianggap tidak layak oleh para ahli. Hal ini terlihat dengan hasil yang masih sangat rendah. Uji kelayakan yang dilakukan oleh para ahli tersebut dilakukan dengan tujuan untuk mengetahui kualitas produk dari aspek media, bahasa, dan materinya.

Uji kelayakan ahli media terhadap media yang dikembangkan bertujuan untuk menguji kelayakan serta memberikan penilaian pada media. Hasil uji kelayakan oleh ahli media pada produk awal dianggap sangat tidak layak, hanya $29,55 \%$, padahal untuk mendapatkan kategori layak harus mendapatkan persentase di atas 80\% (Sudjana, 2005). Artinya produk awal yang dikembangkan masih banyak kekurangan dan perlu perbaikan. Hal ini terlihat pada hasil penilaian yang hanya mendapatkan 13 poin dari skor maksimal 44 poin. Pada uji kelayakan oleh ahli media, semua indikator dianggap sangat kurang, dan hanya kemudahan penggunaan yang dianggap sudah baik.

Ahli bahasa pun menganggap bahwa produk awal yang dikembangkan masih dianggap tidak layak, yaitu. Uji kelayakan oleh ahli bahasa bertujuan untuk menguji kelengkapan bahasa dari segi bahasa yang digunakan. Hasil uji kelayakan aspek bahasa hanya memperoleh $41,67 \%$. Hal ini terlihat pada hasil penilaian yang hanya mendapatkan 10 poin dari skor maksimal 24 poin. Ahli bahasa menganggap bahwa produk awal yang dibuat masih perlu banyak perbaikan, khususnya pada penggunaan bahasa yang efektif, komunikatif, dan dapat membuat siswa mudah memahami konsep.

Penilaian oleh ahli materi memberikan kategori kurang layak pada produk awal yang dibuat, yaitu sebesar $54,17 \%$. Uji kelayakan mendapatkan skor 26 poin dari skor maksimal 48 poin. Validasi ahli materi bertujuan untuk menguji mengenai kelengkapan materi pada produk, kebenaran materi, serta sistematika materi pada media yang dibuat. Beberapa hal yang dianggap sangat kurang oleh ahli materi adalah ketepatan teks, ketepatan bahasa, dan sistematika materi.

Dari hasil uji kelayakan tahap 1 yang menunjukkan kategori kurang layak, maka perlu dilakukan perbaikan-perbaikan terhadap media pembelajaran. Perbaikanperbaikan yang dilakukan didasarkan pada hasil uji kelayakan oleh para ahli di tahap 1.

Tabel 3 merupakan hasil uji kelayakan yang dilakukan oleh ahli media, ahli bahasa, dan ahli materi terhadap media pembelajaran audio visual yang telah melalui proses perbaikan. Proses berbaikan pada media pembelajaran didasarkan pada penilaian yang telah dilakukan oleh tim ahli. Dari hasil uji kelayakan tahap 2, terlihat bahwa media pembelajaran telah peningkatan kualitas. 
Tabel 2. Hasil Uji Kelayakan Tahap 1

\begin{tabular}{llllll}
\hline No. & Penilai & Hasil Penilaian & Skor Maksimal & Persentase & Kategori \\
\hline 1. & Ahli Media & 13 & 44 & $29,55 \%$ & Tidak Layak \\
2. & Ahli Bahasa & 10 & 24 & $41,67 \%$ & Tidak Layak \\
3. & Ahli Materi & 26 & 48 & $54,17 \%$ & Kurang layak \\
\hline
\end{tabular}

Tabel 3. Hasil Uji Kelayakan Tahap 2

\begin{tabular}{llllll}
\hline No. & Penilai & Hasil Penilaian & Skor Maksimal & Persentase & Kategori \\
\hline 1. & Ahli Media & 40 & 44 & $90,91 \%$ & Sangat Layak \\
2. & Ahli Bahasa & 22 & 24 & $91,67 \%$ & Sangat Layak \\
3. & Ahli Materi & 42 & 48 & $87,5 \%$ & Sangat layak \\
\hline
\end{tabular}

Uji kelayakan yang dilakukan oleh ahli media menunjukkan video pembelajaran dianggap sangat layak, yaitu 90,91\%. Hal ini terlihat hasil penilaian ahli media yang memberikan skor 40 poin dari skor maksimal 44 poin. Penilaian ahli media menunjukkan bahwa video pembelajaran yang telah direvisi mengalami peningkatan pada semua indikator penilaian.

Peningkatan hasil uji kelayakan juga diperoleh dari ahli bahasa yang menganggap video pembelajaran sangat layak, yaitu 91,67\%. Ahli media memberikan skor maksimal pada aspek kejelasan dalam memberikan informasi, keterbacaan, penggunaan yang efektif dan efisien, serta bahasa yang komunikatif. Dari hasil penilaian ahli media ini, video pembelajaran mendapatkan skor 22 poin dari skor maksimal 24 poin. Hal ini menunjukkan video pembelajaran yang telah direvisi mengalami peningkatan kualitas.

Pada uji kelayakan yang dilakukan oleh ahli materi juga menunjukkan adanya peningkatan kualitas video pembelajaran yang dikembangkan. Hasil uji kelayakan ahli media, video pembelajaran dikategorikan sangat layak untuk digunakan pada proses pembelajaran. Hal ini didasarkan pada persentase sebesar $87,5 \%$. Total skor dari uji kelayakan yang dilakukan ahli materi sebesar 42 poin dari skor maksimal 48 poin. Dari penilaian yang dilakukan oleh ahli materi menunjukkan bahwa video pembelajaran telah sesuai dengan Kompetensi Inti dan
Kompetensi Dasar yang memuat materi menulis teks narasi untuk kelas VII.

Berdasarkan uji kelayakan tahap 2 yang dilakukan oleh tiga ahli, media pembelajaran audio visual yang telah dikembangkan dikategorikan sangat layak untuk digunakan dalam proses pembelajaran. Akan tetapi, mengingat masa pandemi Covid-19, maka media pembelajaran hasil pengembangan ini belum dapat diterapkan sepenuhnya di sekolah.

\section{Pembahasan}

Pengembangan media audio visual menulis teks narasi merupakan upaya yang dilakukan untuk menghasilkan proses pembelajaran efektif. Pengembangan media pembelajaran ini didasarkan pada analisis masalah dan analisis kebutuhan yang telah dilakukan sebelumnya pada guru-guru mata pelajaran Bahasa Indonesia SMP. Dari hasil analisis masalah dan analisis kebutuhan diketahui bahwa siswa belum memiliki kemampuan menulis yang maksimal.

Selama ini kemampuan menulis siswa menemukan berbagai hambatan, salah satunya kekurangmampuan memilih perbendaharaan kata, apalagi membuat sebuah kalimat efektif. Siswa terkadang memilih kata yang tidak sesuai dengan KBBI dan memilih menggunakan bahasa daerah. Selain itu, menurut siswa, menulis narasi atau menulis paragraf lainnya memang lebih sulit untuk memilih diksi yang benar dan menyusun sebuah kalimat 
menjadi kalimat efektif. Terkadang siswa bingung untuk menuangkan ide-ide tersebut menjadi sebuah cerita yang baik. Dalam menulis teks narasi siswa lebih memilih tema yang diambil berdasarkan kesukaannya terhadap komik atau berdasarkan film yang ditonton. Di sisi lain, pembelajaran bahasa Indonesia jarang menggunakan media pembelajaran yang inovatif. Selain itu, fasilitas media yang digunakan selama pembelajaran kurang inovatif sehingga siswa membutuhkan adanya variasi baru dalam belajar.

Dari permasalahan tersebut maka perlu dikembangkan sebuah media pembelajaran yang inovatif dan lebih interaktif untuk menunjang proses pembelajaran Bahasa Indonesia, khususnya pada materi menulis teks narasi. Media pembelajaran yang dianggap cocok untuk dikembangkan adalah media pembelajaran audio visual berupa video pembelajaran. Hal ini diperkuat dengan Anderson (1987) bahwa video pembelajaran dapat mengembangkan aspek kognitif, afektif, dan psikomotor siswa. Pada ranah kognitif, siswa dapat mengobservasi rekreasi dramatis dari kejadian sejarah masa lalu dan rekaman aktual dari peristiwa terkini, karena unsur warna, suara dan gerak di sini mampu membuat karakter berasa lebih hidup. Dengan melihat video, setelah atau sebelum membaca, dapat memperkuat pemahaman siswa terhadap materi ajar. Pada ranah afektif, video dapat memperkuat siswa dalam merasakan unsur emosi dan penyikapan dari pembelajaran yang efektif.

Pada ranah psikomotorik, video memiliki keunggulan dalam memperlihatkan bagaimana sesuatu bekerja, video pembelajaran yang merekam kegiatan motorik/gerak dapat memberikan kesempatan pada siswa untuk mengamati dan mengevaluasi kembali kegiatan tersebut. Sebagai bahan ajar non cetak, video kaya akan informasi untuk diinformasikan dalam proses pembelajaran karena pembelajaran dapat sampai ke peserta didik secara langsung. Selain itu, video menambah dimensi baru dalam pembelajaran, peserta didik tidak hanya melihat gambar dari bahan ajar cetak dan suara dari program audio, tetapi di dalam video, peserta didik bisa memperoleh keduanya, yaitu gambar bergerak beserta suara yang menyertainya.

Hasil uji kelayakan tahap 2 yang dilakukan oleh ahli media, ahli bahasa, dan ahli materi menunjukkan bahwa media pembelajaran audio visual yang dikembangkan telah memenuhi kelayakan untuk digunakan pada proses pembelajaran. Akan tetapi dengan adanya pandemi Covid-19, maka proses uji coba lapangan (uji beta dan uji efektivitas) pada pembelajaran belum dapat dilaksanakan. Sebenarnya dengan adanya media pembelajaran audio visual yang dikembangkan dapat memberikan manfaat dalam proses pembelajaran, seperti memperlancar interaksi antara guru dengan siswa sehingga kegiatan pembelajaran akan lebih efektif dan efisien (Aqib, 2013).

Pada proses pembelajaran teks narasi, adanya media pembelajaran audio visual dapat menyeragamkan penyampaian materi pelajaran. Sebagaimana diketahui bahwa setiap guru mungkin mempunyai penafsiran yang berbeda-beda terhadap suatu konsep materi pelajaran tertentu. Menurut Falahudin (2014) dengan bantuan media pembelajaran, penafsiran yang beragam tersebut dapat dihindari sehingga dapat disampaikan kepada siswa secara seragam. Setiap siswa yang melihat atau mendengar uraian suatu materi pelajaran melalui media yang sama, akan menerima informasi yang persis sama seperti yang diterima oleh siswa-siswa lain. Dengan demikian, media juga dapat mengurangi terjadinya kesenjangan informasi di antara siswa.

Hardianti \& Asri (2017) juga mendukung penggunaan media pembelajaran audio visual berupa video 
pembelajaran. Media video sangat efektif dalam keterampilan menulis karangan. Ada perbedaan yang signifikan antara siswa yang diajarkan keterampilan menulis tidak menggunakan media video dengan siswa yang diajarkan menggunakan media video. Pada siswa yang diajarkan menggunakan media video mendapatkan nilai yang cukup tinggi, artinya media video dapat meningkatkan pemahaman siswa, khususnya pada kemampuan pedagogis. Dengan adanya pendapat ini, pengembangan media pembelajaran audio visual yang dilakukan sangat penting. Hal ini juga diperkuat dengan pendapat Anderson (1987) yang telah dipaparkan sebelumnya.

\section{PENUTUP}

Berdasarkan hasil pengembangan yang dilakukan, maka disimpulkan beberapa hal berikut. Pertama, pengembangan media pembelajaran audio visual ini dilakukan untuk membantu guru menyediakan penunjang pembelajaran yang lebih inovatif, khususnya pada pembelajaran menulis teks narasi. Proses pengembangan dilakukan dengan mengikuti konsep Alessi \& Trollip (2001) yang meliputi tahap planning (perencanaan), design (mendesain model), dan development (pengembangan). Penggunaan model pengembangan ini karena model ini memang dikhususkan untuk mengembangkan multimedia pembelajaran — dalam penelitian ini adalah media audio visual (video).

Hasil uji kelayakan dari tiga ahli adalah sebagai berikut. Hasil uji kelayakan ahli media mendapat skor 40 dengan persentase $90,91 \%$ sehingga dikategorikan sangat layak. Ahli bahasa memberikan skor uji kelayakan sebesar 22 dengan persentase $91,67 \%$ dan dikategorikan sangat layak. Uji kelayakan dari ahli materi mendapat nilai sebesar 42 dengan persentase $87,5 \%$ dan dikategorikan sangat layak. Berdasarkan hasil tersebut dapat disimpulkan bahwa media audio visual yang dikembangkan telah memenuhi kriteria sangat layak.

\section{DAFTAR PUSTAKA}

Alessi, S. M., \& Trollip, S. R. (2001). Multimedia for Learning Method And Development. Massachusetts: Alin \& Bacon.

Ardiyanti, W., Safitri, S., \& Susanti, L. R. R. (2019). Pengembangan Media Pembelajaran Menggunakan Windows Movie Maker pada Mata Pelajaran Sejarah Kelas XI Sekolah Menengah Atas. Criksetra: Jurnal Pendidikan Sejarah, 8(1), 53-72. Diambil dari https://ejournal.unsri.ac.id/index.p $\mathrm{hp} /$ criksetra/article/view/7442

Arsyad, A. (2016). Media Pembelajaran. Jakarta: Raja Grafindo Persada.

Devi, P. C., Hudiyono, Y., \& Mulawarman, W. G. (2018). Pengembangan Bahan Ajar Menulis Teks Prosedur Kompleks dengan Model Pembelajaran Discovery Learning Menggunakan Media Audio Visual (Video) di Kelas XI SMA Negeri 1 Samarinda. Diglosia: Jurnal Kajian Bahasa, Sastra, dan Pengajarannya, 1(2), 101-114. https://doi.org/10.30872/diglosia.v $1 \mathrm{i} 2.13$

Hasibuan, M. I. (2014). Model Pembelajaran CTL (Contextual Teaching and Learning). Logaritma, 2(1), $1-12$.

Munandar, A. H., \& Surjono, H. D. (2017). Pengembangan E-Learning Berbasis Moodle untuk Meningkatkan Pemahaman Isi Teks Anekdot pada Siswa SMA Kelas X. Jurnal Teknologi Informasi dan Komunikasi dalam Pendidikan, 4(1), 1-12.

Nurhadi. (2002). Pendekatan Kontekstual (Contextual Teaching and Learning). Jakarta: Direktorat Jenderal Pendidikan Dasar dan Menengah, Departemen Pendidikan Nasional.

Santyasa, I. W. (2011). Pembelajaran Inovatif. 
Singaraja: Universitas Pendidikan Ganesha.

Sudjana, N. (2005). Media Pengajaran (Penggunaan dan Pembuatannya). Bandung: Sinar Baru Algensindo.

Syah, I. M., \& Risnawati, S. (2019). Keefektifan Media Video terhadap Aktivitas dan Hasil Belajar Narasi di SD. Elementary, 7(1), 137-148.

Winaya, I. G., Santyasa, I. W., \& Rasana, I. D. P. R. (2013). Penerapan Pembelajaran Kontekstual Berbantuan Video untuk Meningkatkan Prestasi Belajar Menulis Narasi Siswa Kelas VII-5
SMP Negeri 3 Banjar Tahun 2012/2013. Jurnal Teknologi Pembelajaran Indonesia, 3(1). Diambil dari https://ejournalpasca.undiksha.ac.id/index.php/jurn al_tp/article/view/730

Yulianti, U. H. (2020). Pengembangan Media Pembelajaran Interaktif Menulis Teks Hasil Observasi Bermuatan Konservasi bagi Peserta Didik Kelas VII SMP. Jurnal Pendidikan Bahasa dan Sastra Indonesia, 9(1), 1-7. 